son et al. 1968; Cuthbertson \& Tilstone, r968; Cuthbertson, 1970; Tilstone \& Cuthbertson, 1970$)$. Drier conditions $(20 \%$ relative humidity) are indicated in burns (Barr et al. 1968).

The author wishes to express his indebtedness to the Medical Research Council for a grant in aid of this research.

\title{
REFERENCES
}

Ballantyne, F. C., Cuthbertson, D. P., Fleck, A. \& Tilstone, W. J. (1969). Int.Congr. Nutr. vin Prague, I 969.

Barr, P.-O., Birke, G., Liljedahl, S.-O. \& Plantin, L.-O. (1968). Lancet i, I64.

Caldwell, F. T. (r962). Ann. Surg. 155, rx9.

Caldwell, F. T. (1970). In Energy Metabolism in Trauma, Ciba Foundation Symposium, p. 23. London: Churchill.

Cuthbertson, D. P. (1970). Br. 7. Surg. 57, 718 .

Cuthbertson, D. P. \& Tilstone, W. J. (1968). Am. F. clin. Nutr. 21, 91 I.

Cuthbertson, D. P., Smith, C. M. \& Tilstone, W. J. (1968). Br. F. Surg. 55, 513.

Cuthbertson, D. P., Tilstone, W. J. \& Green, J. A. (1969). Lancet i 987.

Davies, J. W. L. (1970). F. clin. Path. 23, suppl. no. 4 (Royal College of Pathology), p. 56.

Medical Research Council (1951). Spec. Rep. Ser. med. Res. Coun. no. 277.

Ministry of Health (1964). Rep. Publ. Hlth med. Subj. no. i I I, p. 49. London: H.M. Stationery Office.

Tilstone, W. J. \& Cuthbertson, D. P. (1970). In Energy Metabolism in Trauma, Ciba Foundation Symposium, p. 43. London: Churchill.

\section{Protein metabolism after injury}

\section{By A. Fleck, Department of Biochemistry, Royal Infirmary, Glasgow $C_{4}$}

Two authoritative reviews of various aspects of trauma have appeared recently (Porter \& Knight, 1970; Sevitt \& Stoner, 1970). For this reason it seemed apposite to consider mainly the nutritional aspects of the effects of injury on protein metabolism.

The first observations, which demonstrated altered metabolism after trauma, were made on humans (patients in Glasgow Royal Infirmary) by Sir David Cuthbertson (Cuthbertson, 1929). In a series of papers (see Cuthbertson, 1964), he demonstrated that the increased urinary excretion of nitrogen, sulphur and phosphorus was maximal between the $3^{\text {rd }}$ and 8 th days after injury and that there were parallel increases in body temperature, pulse rate and oxygen consumption. He also found that the daily loss of $\mathrm{N}$ could be up to $23 \mathrm{~g}$ after severe injury (Cuthbertson, I930, I932). It now seems to be generally accepted that the magnitude of the response is related direct to the degree of trauma, although environmental temperature (Caldwell, I970; Tilstone \& Cuthbertson, I970; Davies, Liljedahl \& Birke, 1969) and previous diet (Munro \& Cuthbertson, 1943; Fleck \& Munro, r 963) modify the response. Human males after a moderate injury such as closed fracture of the tibia and fibula have a net loss of about $5 \mathrm{~g} \mathrm{~N} / \mathrm{d}$ for several days (Cuthbertson, unpublished observations). These patients before injury were generally normal fit men and were maintained in an environmental temperature of 
$20^{\circ}$ after injury. This net loss is equivalent to almost half the daily protein intake.

Many studies of the changes in plasma proteins after injury have been reported (see Owen, I967). In the earlier reports salt fractionation methods were used and these were followed by paper electrophoretic techniques. There is general agreement that, after injury, serum or plasma albumin falls and returns to normal slowly, $a_{1}$-globulin increases briefly, and $a_{2}$ - and $\beta$-globulins generally remain unchanged although $\alpha_{2}$-globulin may also increase slightly. $\gamma$-Globulin, depending on the nature and severity of the injury and presence of infection, may rise - it certainly does so in burns (Davies et al. 1969). More recent studies of the acute phasereacting proteins (AP reactants) using mainly immunodiffusion techniques have demonstrated a fairly characteristic time-sequence of response, although no specific reaction to a particular type of trauma has been noted (Koj, I970). The AP reactants include haptoglobin, fibrinogen, caeruloplasmin, seromucoid, C-reactive protein, $a_{2}$-AP globulin, $a_{1}$-acid glycoprotein and $a_{1}$-antitrypsin. C-reactive protein responds to trauma most rapidly in man, usually within $24 \mathrm{~h}$, being normally undetectable in plasma. The considerable changes in fibrinogen metabolism after injury have been summarized by $\operatorname{Koj}(1970)$. In rabbits the highest values of fibrinogen synthesis rates occurred after injection of endotoxin or turpentine and were up to seven times greater than normal and approximately equal to the synthesis rate of albumin. In contrast, the fractional catabolic rate of fibrinogen did not change. These observations are consonant with the persistence of high plasma fibrinogen levels observed after injury (Davies, Ricketts \& Bull, 1966).

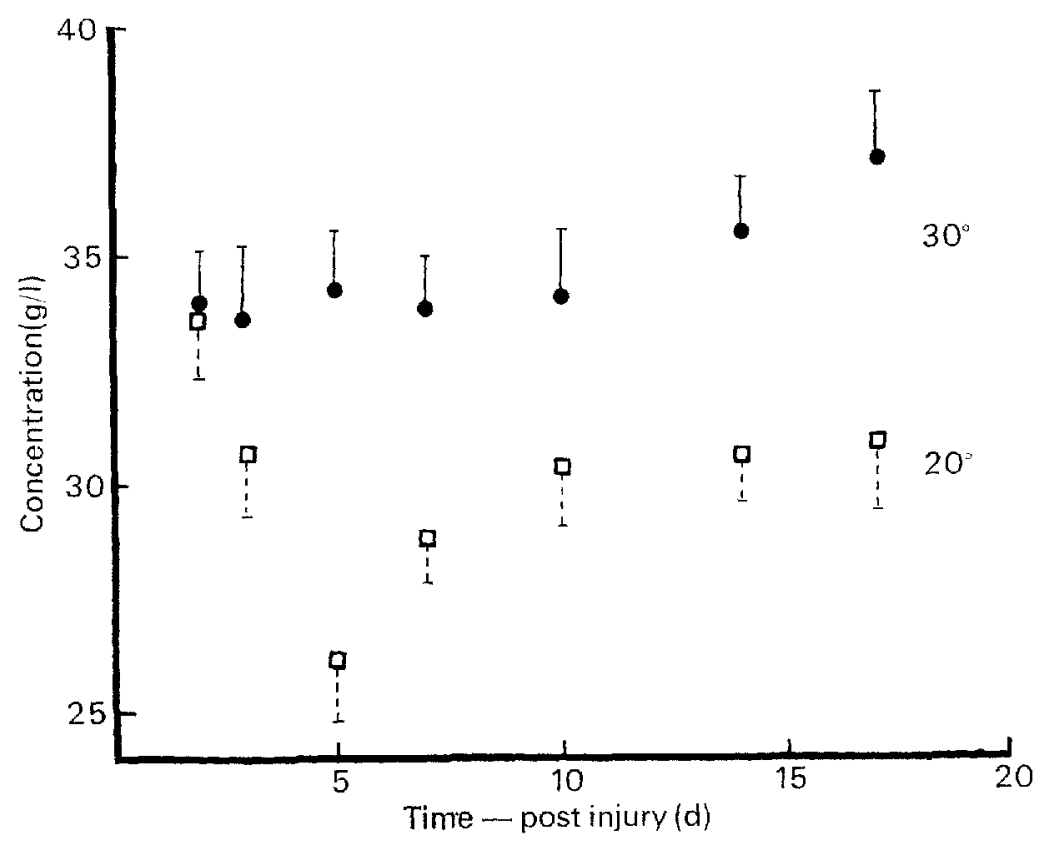

Fig. I. The effect of injury on the concentration of plasma albumin of patients. $\square$, maintained at $20^{\circ} ;$, maintained at $30^{\circ}$. The vertical lines indicate the standard errors. The normal concentration of plasma albumin is $35-55 \mathrm{~g} / \mathrm{l}$. 
Quantitatively the most significant plasma protein in which changes can be demonstrated after injury is albumin. When patients are maintained at normal ward temperatures $\left(20^{\circ}\right)$ the concentration of albumin is found to fall fairly rapidly after injury, attaining a minimum level at day 5 and slowly rising thereafter towards normal ( $35 \mathrm{~g} / \mathrm{l})$ (Fig. I). In contrast, in patients exposed to an environment of $30^{\circ}$ this response is virtually abolished and significantly higher plasma albumin levels than at $20^{\circ}$ are observed throughout the post-injury period. Similarly, in patients maintained at the warmer environmental temperature $\left(30^{\circ}\right)$ the changes in $\alpha_{1}-, a_{2}$ and $\gamma$-globulins induced by injury were minimized. This did not, however, occur with all the AP reactants studied. Changes in transferrin, caeruloplasmin and $\alpha_{1}$ acid glycoprotein were similar at both temperatures, but C-reactive protein concentration was greater in patients maintained in the $20^{\circ}$ environment than in those in the $30^{\circ}$ cubicles (Ballantyne and Fleck, unpublished observations). The twenty patients studied by us were orthopaedic cases and the most common injury was fracture of a lower limb. We have also studied catabolism with ${ }^{125}$ I-labelled human serum albumin in these patients. By the 6th day after injury there is a notable difference in intravascular albumin content in the two groups - it is lower in those maintained at $20^{\circ}$, but both groups had subnormal intravascular albumin content in comparison with normal controls (Table 1 ). Studies of the fractional

\section{Table I. Intravascular (IV) content and catabolic rate of albumin after injury}

(Mean values with their standard errors)

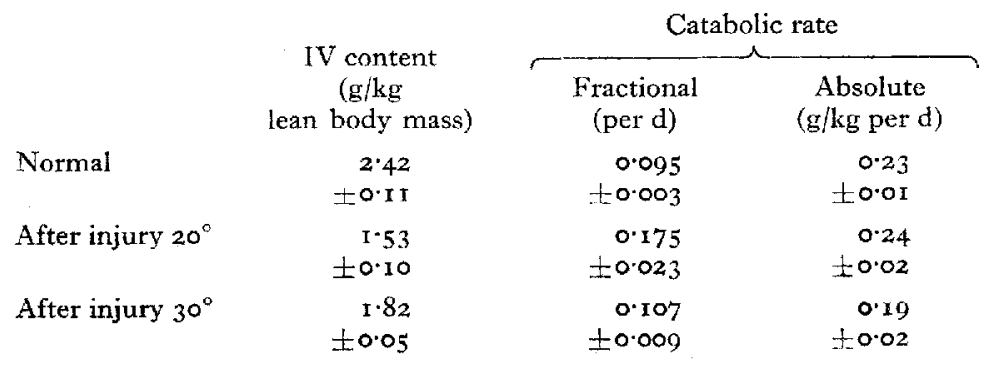

catabolic rate of albumin after injury also showed differences between the groups at the two environmental temperatures (Table I). The group at $20^{\circ}$ had much higher fractional catabolic rates than the $30^{\circ}$ group, which were not greatly different from normal. In contrast with these findings and with fibrinogen (see Koj, 1970), injury had no effect on the absolute catabolic rate of albumin.

The study of protein metabolism after injury is complicated because the subject or experimental animal is obviously not in a 'steady state'. Catabolic rates are usually determined in studies of about $\mathrm{I}_{4} \mathrm{~d}$ duration and in the 'non-steady state' the catabolic rate is calculated daily from the ratio of urine radioactivity to plasma specific radioactivity (McFarlane, 1964). In contrast, the determination of the rate of albumin synthesis in man may be achieved from values obtained in a period of about $6 \mathrm{~h}$ (Reeve, Pearson \& Martz 1963; McFarlane, I963). Although the difficulty 
of the non-steady state remains, changes during this shorter period can usually be ignored. These problems of determining synthetic and catabolic rates of plasma proteins have been discussed recently by Rothschild \& Waldmann (1970). Using a slightly modified $\left[{ }^{14} \mathrm{C}\right]$ carbonate method (Koj \& McFarlane, 1968), our preliminary studies in four rabbits suggest that $\mathrm{r} 8 \mathrm{~h}$ after fracture of the femur albumin synthesis is decreased to about $25 \%$ below the normal level (Table 2) (Ballantyne, Tilstone and Fleck, unpublished observations). These results are compatible with

Table 2. Albumin synthesis in rabbits after injury

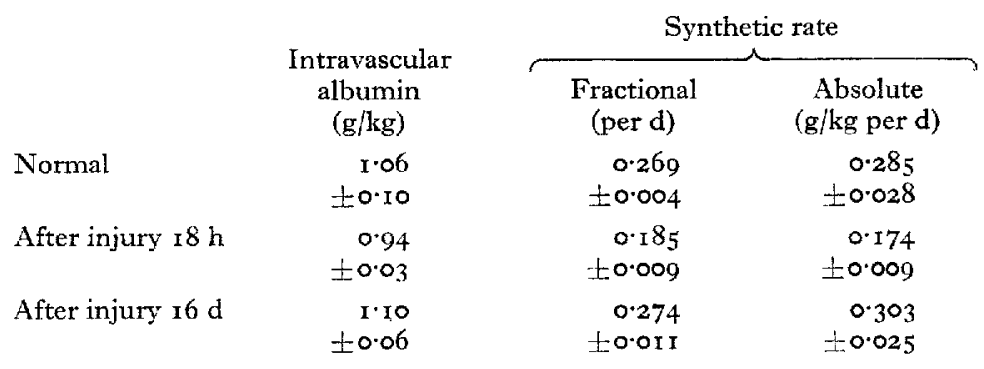

the observed fall in plasma albumin concentration after injury and the unchanged absolute catabolic rate. They are also consistent with the changes in the polysome patterns of rat liver, which we found to be maximal about i $8 \mathrm{~h}$ after injury (Fleck, Wunner, Henderson, Ballantyne \& Tilstone, I971). However, other workers have reported different findings. For example, Koj \& McFarlane (1968) found that albumin synthesis was increased after the injection of endotoxin into rabbits and Tsukada, Moriyama, Umeda \& Lieberman (r968) found increased aggregation of liver polysomes $18 \mathrm{~h}$ after partial hepatectomy. The explanation for the discrepancies may be the different naturc of the trauma; partial hepatectomy will lead to a specific 'recovery' response by the liver.

In attempting to assess the nutritional significance of the changes in plasma albumin a simple calculation led to a surprising result. The plasma albumin concentration on the 6th day after injury allowed a rough estimate to be made of the apparent loss of body albumin - this was in the region of $7 \circ \mathrm{g}$. However, the absolute catabolic rate remained unchanged by injury at approximately io $g$ per $d$. The incompatibility of these figures could be taken to support the proposal by Mouridsen \& Faber (1966) that changes in plasma albumin levels after injury are due to losses into the wound site. An altered distribution of body albumin probably also contributes. However, it seems unlikely that the extent of loss into the wound would be influenced significantly by a change of environmental temperature to $30^{\circ}$. It would seem that a careful study of albumin metabolism and distribution after injury is warranted using, for example, the immunochemical technique of Katz, Bonorris \& Sellers $(1970)$. Perhaps the only conclusion one can draw at this stage is that a low level of plasma albumin in an individual patient does not necessarily indicate inadequate protein nutrition. Because of the lack of change in its catabolic rate, one may also conclude that albumin does not contribute significantly to the increased $\mathrm{N}$ excretion which follows injury. 
'These findings are of interest in relation to the results of Hoffenberg, Black \& Brock (1966), who showed that in protein malnutrition not only was there a lowered plasma albumin but that the absolute catabolic rate was decreased. In subsequent studies on rats it was shown that the rate of synthesis of albumin declined from the commencement of protein depletion, but that the catabolic rate remained constant for several days before also falling (Kirsch, Frith, Black \& Hoffenberg, 1968). It may be that the effects of injury on albumin are so relatively short that only synthesis will be affected and not catabolism.

Having eliminated the plasma proteins as a significant source of the post-injury protein catabolic loss other sources must be considered. If as Wray (Ig68) has shown there is some loss of liver protein, there is rapid recovery because Fleck \& Munro ( 1963 ) found no changes in the livers of rats $7 \mathrm{~d}$ after fracture of the femur. Cuthbertson in as yet unpublished observations has found no significant differences in the weights or protein content of other organs. From the ratios of urinary $\mathrm{N}$ to $S, P$, potassium and creatine it is tempting to conclude that muscle is the major source of loss. Recent studies (B. F. Fell, W. J. Tilstone and D. P. Cuthbertson, unpublished) have shown an increased loss of zinc in the urine which parallels the creatine output. Since about $65 \%$ of the body zinc is located in muscle, this seems to support the hypothesis. Here again there is a contrast with protein malnutrition. For example Fleck \& Munro ( 1963 ) found marked differences in liver protein, and plasma albumin content and turnover in protein-depleted and protein-fed rats; no effect on albumin or liver protein was detected after injury so that the extensive protein loss must have originated elsewhere.

As with the plasma albumin changes, the increased urinary loss of $\mathrm{N}$ can be extensively reduced if the patients are transferred to a warm $\left(30^{\circ}\right)$ environment. A further related and interesting observation was made in the group of patients studied in Glasgow Royal Infirmary by Tilstone \& Cuthbertson (1970). They were able to show that, as in normal individuals, there was a correlation between total dietary energy and urinary $\mathrm{N}$ in patients maintained at the higher environmental temperature $\left(30^{\circ}\right)$ after injury, but in the patients maintained at the normal ward temperature of $20^{\circ}$ there was no significant linear correlation either between urine$\mathrm{N}$ and food energy or between urine- $\mathrm{N}$ and food- $\mathrm{N}$.

The evidence I have reviewed so far relates mainly to biochemical studies and in summary these indicate: firstly, that the net loss of $\mathrm{N}$ in the urine is probably derived mainly from the carcass (or muscle), secondly that the plasma proteins probably contribute little to the urine- $N$, and thirdly, that many of the changes including the net loss of protein can be largely prevented by maintaining the patient in a warm environment $\left(30^{\circ}\right)$ after injury.

Studies of basal metabolism and changes in body composition after injury recently reviewed by Kinney, Duke, Long \& Gump (1970) and by Kinney, Long \& Duke (1970) throw some further light on the role of protein metabolism in the response to trauma. After injury, the intracellular space decreases due to associated loss of protein and cell water and in addition there is a loss of body fat. The increased energy expenditure after injury is of the order of $10-20 \%$ in skeletal injuries, $15-50 \%$ 
in infections and 40-100\% after burns. Of the increased calories, $7590 \%$ is obtained from fat and the remainder from protein which may contribute from $12-22 \%$ of the calories. The weight loss can be explained on the basis that lean tissue contributes only approximately I $\mathrm{kcal} / \mathrm{g}$, whereas fat contributes $9 \mathrm{kcal} / \mathrm{g}$. One may speculate that either the response to trauma results from disordered control mechanisms or that the response as Kinney, Duke et al. (1970) have suggested is such as to promote protein breakdown in order to provide carbohydrate intermediates for metabolism.

It is a pleasure to acknowledge collaboration with Sir David Cuthbertson, Dr W. J. Tilstone and Mrs F. C. Ballantyne in the metabolic studies on patients.

This work was carried out while in receipt of a grant from the Medical Research Council.

\section{REFERENCES}

Caldwell, F. T. (1970). In Energy Metabolism in Trauma, Ciba Foundation Symposium, p. 23. [R. Porter and J. Knight, editors]. London: J. \& A. Churchill.

Cuthbertson, D. P. (1929). Biochem. F. 23, 1328 .

Cuthbertson, D. P. (1930). Biochem. F. 24, 1244.

Cuthbertson, D. P. (1932). Q. $\mathscr{H}$ Med. 25, 233 .

Cuthbertson, D. P. (1964). In Mammalian Protein Metabolism, Vol. 2, p. 373, [H. N. Munro and J. B. Allison, editors]. New York \& London: Academic Press.

Davies, J. W. L., Ricketts, C. R. \& Bull, J. P. (x966). Clin. Sci. 30, 305.

Davies, J. W. L., Liljedahl, S.-O. \& Birke, G. (1969). Injury I, 43.

Fleck, A. \& Munro, H. N. (r963). Metabolism 12, $78_{3}$.

Fleck, A., Wunner, W. H., Henderson, A. R., Ballantyne, F. C. \& Tilstone, W. J. (I971). Proc. Nutr. Soc. 30, 42 .

Hoffenberg, R., Black, E. \& Brock, J. F. (1966). F. clin. Invest. 45, I43.

Katz, J., Bonotris, G. \& Sellers, A. L. (1970). Clin. Sci. 39, 725.

Kinney, J. M., Long, C. L. \& Duke, J. H. Jr (1970). In Energy Metabolism in Trauma, Ciba Foundation Symposium, p. ro3. [R. Porter and J. Knight, editors]. London: J. \& A. Churchill.

Kinney, J. M., Duke, J. H. Jr, Long, C. L. \& Gump, F. E. (1970). In The Pathology of Trauma, F. clin. Path. 23, suppl. no. 4 (Royal College of Pathology) p. 65 [S. Sevitt and H. B. Stoner, editors].

Kirsch, R., Frith, L., Black, E. \& Hoffenberg, R. (1968). Nature, Lond. 2r7, 578.

Koj, A. \& McFarlane, A. S. (x968). Biochem. \%. ro8, r 37.

Koj, A. (1970). In Energy Metabolism in Trauma, Ciba Foundation Symposium, p. 79 [R. Porter and J. Knight, editors]. London: J. \& A. Churchill.

McFarlane, A. S. (1963). Biochem. $\mathscr{7} .89,277$.

McFarlane, A. S. (I964). In Mammalian Protein Metabolism, Vol. I, p. 297 [H. N. Munro and J. B. Allison, editors]. New York \& London: Academic Press.

Mouridsen, H. T. \& Faber, M. (I966). Lancet ii, 723.

Munro, H. N. \& Cuthbertson, D. P. (1943). Biochem. $\%$. 37, xii.

Owen, J. A. (1967). Adv. clin. Chem. 9, 2. [H. Sobotka and C. P. Stewart, editors]. New York \& London: Academic Press.

Porter, R. \& Knight, J. (editors). (1970). Energy Metabolism in Trauma, Ciba Foundation Symposium. London: J. \& A. Churchill.

Reeve, E. B., Pearson, J. R. \& Martz, D. C. (rg63). Science, N.Y. r39, 914.

Rothschild, M. A. \& Waldmann, T. A. (editors) (1970). Plasma Protein Metabolism-Regulation of Synthesis, Distribution and Metabolism. New York \& London: Academic Press.

Sevitt, S. \& Stoner, H. P. (editors) (1970). The Pathology of Trauma. F. clin. Path. 23, suppl. no. 4. (Royal College of Pathology),

Tilstone, W. J. \& Cuthbertson, D. P. (1970). In Energy Metabolism in Trauma, Ciba Foundation Symposium, p. 43 [R. Porter and J. Knight, editors]. London: J. \& A. Churchill.

'Tsukada, K., Moriyama, 'T., Umeda, T. \& Lieberman, I. (r 968). F. biol. Chem. 243, I I60.

Wray, J. P. (1968). F. Trauma 7,811. 